\title{
Evaluation of the concomitant use of two different EIA tests for HIV screening in blood banks
}

\author{
Marcia M. Otani, ${ }^{1}$ Nanci A. Salles, ${ }^{1}$ Angela M.E. Barreto, ${ }^{1}$ \\ Claudia C. Barreto, ${ }^{1}$ Dalton F. Chamone, ${ }^{1,2}$ and Ester C. Sabino ${ }^{1}$
}

ABSTRACT Objective. In 1998, the Brazilian Ministry of Health made it mandatory for all blood banks in the country to screen donated blood for human immunodeficiency virus (HIV) concomitantly using two different enzyme immunoassay (EIA) tests. Concerned with the best use of available resources, our objective with this study was to evaluate the usefulness of conducting two EIA screening tests instead of just one.

Methods. We analyzed data from 1999 through 2001 obtained by testing 698191 units of donated blood using two EIA HIV screening tests concomitantly at the Pro-Blood Foundation/Blood Center of São Paulo (Fundação Pró-Sangue/Hemocentro de São Paulo), which is a major blood center in the city of São Paulo, Brazil. All samples reactive in at least one of the two EIA tests were submitted for confirmation by a Western blot (WB) test, and the persons who had donated those samples were also asked to return and provide a follow-up sample. Results. Out of the 698191 blood units that were donated, 2718 of them (0.4\%) had to be discarded because they were reactive to at least one of the EIA tests. There were two WB-positive donation samples that were reactive in only one HIV EIA screening test. On their followup samples, both donors tested WB-negative. These cases were considered false positive results at screening. Of the 2718 donors who were asked to return and provide a follow-up sample, 1576 of them (58\%) did so. From these 1576 persons, we found that there were two individuals who had been reactive to only one of the two EIA screening tests and who had also been negative on the WB at screening but who were fully seroconverted on the follow-up sample. We thus estimated that, in comparison to the use of a single EIA screening test, the use of two EIA screening tests would detect only one extra sample out of 410700 units of blood.

Conclusions. Our data do not support the use of two different, concomitant EIA screening tests for HIV. The great majority of HIV-positive donors have already seroconverted and will be detected using only a single EIA screening test. Only persons who are going through the process of seroconversion may be missed by using a single EIA test and detected using two EIAs for screening. To screen out these individuals and decrease the residual risk of HIV transmission from the blood donated in our center, the use of other techniques, such as nucleic acid testing (NAT) or a p24 antigen assay, would be more effective.

Key words Blood banks, blood donors, HIV, Brazil.

1 Fundação Pró-Sangue/Hemocentro de São Paulo, São Paulo, São Paulo, Brazil. Send correspondence to: Ester C. Sabino, Fundação Pró-Sangue/ Hemocentro de São Paulo, Av Dr Enéas de Carvalho Aguiar 155, 1 andar, São Paulo, SP 05409-
010, Brazil; e-mail: sabinoec@uol.com.br; fax: (5511) 30888317.

2 Faculdade de Medicina da Universidade de São Paulo, Departamento de Hematologia e Hemoterapia, São Paulo, São Paulo, Brazil.
The standard procedure for testing blood donation samples for human immunodeficiency virus (HIV) includes an enzyme immunoassay (EIA) 
screening test followed by a confirmatory test, such as the Western blot or immunofluorescence, on samples that are reactive. Successive generations of EIA tests for HIV have improved in their sensitivity and specificity and now have a sensitivity of nearly $100 \%$ $(1,2)$. Because of this high sensitivity, it is standard practice in blood banks worldwide to use a single EIA test for HIV screening (3-5).

Around three million blood units are collected per year in Brazil. The Brazilian Health Surveillance Agency (Agência Nacional de Vigilância Sanitária, or ANVISA), an agency of the Government of Brazil, is responsible for setting rules for all the blood centers in the country, including ones that are governmental, private, or nonprofit. Screening for HIV has been a major concern in Brazil, and the Brazilian Ministry of Health has made efforts to have the public blood collection system improved over the past 15 years. Today, the procedures for blood collection in Brazil are similar to what is done in European countries and in the United States of America: paid donation is forbidden, and voluntary donors are not allowed to donate if they acknowledge risk factors for HIV in their initial interview.

In 1998, with the objective of preventing the transmission of HIV by blood transfusion in Brazil, the Ministry of Health made it mandatory for all blood centers to concomitantly use two different EIA tests to screen for HIV all blood donations made in the country. At that time no data were available on the Brazilian blood donor population as to the sensitivity and specificity of the available serological screening tests.

Concerned with the best use of available resources, it was the objective of our center, the Pro-Blood Foundation/ Blood Center of São Paulo (Fundação Pró-Sangue/Hemocentro de São Paulo [PBF/BCSP]), to evaluate whether the use of two EIA screening tests rather than just one enhanced the ability to detect actual cases of HIV infection. A large blood center in the city of São Paulo, the PBF/BCSP collects around 200000 units of blood per year, or some $50 \%$ of the blood collected in the city. The PBF/BCSP is also the largest blood center in Latin America. The purpose of this study was to evaluate the concomitant use of the two different EIA screening tests for HIV in our center's blood donor population. We present here the results obtained with this dual screening of 698191 samples.

\section{MATERIALS AND METHODS}

From January 1999 to November 2001, a total of 698191 units of blood were collected and tested at the PBF/ BCSP. In 1999 the tests used were the Vironostika HIV Uni-Form plus O (Organon Teknika, Boxtel, Holland) and the Murex ICE-HIV-1.O.2 (Murex, Datford, United Kingdom). For the following two years the Murex kit was replaced by the ORTHO HIV-1/HIV-2 Ab-Capture ELISA Test System (Raritan New Jersey, United States of America). All those tests are considered thirdgeneration assays and are highly sensitive. The cost of the tests in Brazil is around US\$ 1.50 per test.

Any sample reactive in at least one of the two EIA tests was considered initially reactive and was retested in duplicate for the reactive EIA test in the next work shift. If both duplicates were nonreactive, the sample was considered nonreactive for EIA, and the blood unit was used. If at least one of the duplicates was reactive, the sample was considered EIA-reactive, the unit was discarded, and a Western blot (WB) test was also performed. The WB test used was the HIV BLOT 2.2
(Genelabs ${ }^{\circledR}$ Diagnostics, Singapore). A sample was considered WB-positive if it was reactive to the $\mathrm{p} 24$ and gp120/ 160 bands, WB-negative if no bands were seen, and indeterminate if it presented some other pattern.

A letter was sent to all EIA-reactive donors asking them to return so that a follow-up sample could be collected. The follow-up sample was subjected to both EIA tests; if it was reactive to at least one of the EIA tests, it was also subjected to WB testing. Because of the period that it normally took for a letter to be received and for a donor to return, the follow-up samples were generally obtained between 2 and 8 weeks after the initial, donation sample.

\section{RESULTS}

Of the 698191 blood units initially screened with the two different EIA tests, 2718 of them $(0.4 \%)$ had to be discarded for transfusion use because they were reactive to at least one of the EIA screening tests. The WB results on these EIA-positive donation samples are presented in Table 1. Of the 2718 EIA-reactive samples, 639 of them were reactive in both EIA screening tests, and 2079 were reactive to only one of the EIA screening tests.

Of the 639 samples reactive in both EIA screening tests, 535 (84\%) were confirmed positive by WB. Of the 2079 samples that were reactive to only one of the two EIA screening tests, only two of them $(0.1 \%)$ were positive by WB. These two samples both had only weak p24 and gp160 bands on the WB.

TABLE 1. Western blot (WB) results on 2718 blood-donation samples that were reactive to one or two different, concomitant enzyme immunoassay (EIA) screening tests for HIV, São Paulo, Brazil, 1999-2001

\begin{tabular}{lcc}
\hline & $\begin{array}{c}\text { Samples reactive to only one of } \\
\text { the two EIA screening tests } \\
(n=2079)\end{array}$ & $\begin{array}{c}\text { Samples reactive to both } \\
\text { ElA screening tests } \\
(n=639)\end{array}$ \\
\hline Result with WB & & \\
Positive & 2 & 535 \\
Indeterminate & 533 & 40 \\
Negative & 1544 & 64 \\
\hline
\end{tabular}


TABLE 2. Enzyme immunoassay (EIA) and Western blot (WB) test results on follow-up blood samples provided by 1576 blood donors whose initial blood donation had been reactive to one or two EIA screening tests for HIV, São Paulo, Brazil, 1999-2001

\begin{tabular}{lccccc}
\hline & \multicolumn{4}{c}{ Results found at initial screening } \\
\cline { 2 - 3 } & \multicolumn{2}{c}{ Both EIA tests positive } & & One of two EIA tests positive \\
\cline { 2 - 3 } \cline { 5 - 6 } & $\begin{array}{c}\text { WB positive } \\
(n=255)\end{array}$ & $\begin{array}{c}\text { WB ind. or neg. } \\
(n=66)\end{array}$ & & $\begin{array}{c}\text { WB positive } \\
(n=2)\end{array}$ & $\begin{array}{c}\text { WB ind. or neg. } \\
(n=1253)\end{array}$ \\
\hline Follow-up-sample result & 0 & 39 & 1 & 587 \\
EIA negative & 255 & 0 & 0 & 2 \\
WB positive & 0 & 12 & 0 & 153 \\
WB indeterminate & 0 & 15 & 1 & 511 \\
WB negative & & & & & \\
\hline
\end{tabular}

${ }^{a}$ Ind. = indeterminate

${ }^{\mathrm{b}} \mathrm{Neg} .=$ negative.

A follow-up sample was obtained in both of these cases. One of the donors was negative on both of the EIA tests of the follow-up sample, which was collected 45 days after the initial donation, and the person remained negative over the following 3 years when he was tested again for HIV at the blood center as part of the reentry process. The second individual had only one follow-up sample collected, 22 days after the initial donation. In comparison to the tests on the initial donation sample, this person's followup sample was reactive to the same EIA test and had a weak p24 band on the WB test but no longer had a gp160 band. Based on these findings, we concluded that the blood donations in both of these cases had produced false-positive $\mathrm{WB}$ results.

Of the initial 2718 donors whose samples were reactive in at least one EIA screening test, 1576 of them (58\%) returned for follow-up testing. The results with those follow-up samples are shown in Table 2.

There were two donors who were initially weakly reactive to a single EIA test and with a negative WB who seroconverted, being positive to both of the follow-up EIAs and to the follow-up WB. These were the only true HIV-positive samples that were detected with only one of the two EIAs used at screening.

\section{DISCUSSION}

The majority of the latest-generation HIV EIA tests detect all samples with a positive WB $(1,2)$. However, differences in EIA sensitivity have been described for samples obtained during the period of seroconversion, especially for non-subtype B viruses (6). The data presented here support this, since all the WB-positive samples were detected by both EIAs. The only two cases that were reactive to one of two EIA screening tests and positive on the WB at screening turned out to be falsepositives. As previously described (7-9), false-positive results on the WB may be caused by cross-contamination with a positive sample, labeling errors, or nonspecific reactivity to monomeric and multimeric forms of gp41.

During seroconversion, EIA reactivity precedes WB positivity by about 3 days. The two seroconverter samples detected in this study were weakly positive by one EIA screening test and were WB-negative at screening. The follow-up samples for these two donors were positive by both EIA tests as well as the WB. One of these follow- up samples was collected 4 weeks after the initial blood donation, and the other was collected a year after the initial donation.

Our study shows that the use of two different, concomitant EIA screening tests detected 2 seroconversion samples from among the 1576 donors who returned for follow-up. This set of 1576 donors represents $58 \%$ of the original reactive donor population of 2718 persons. Therefore, we can estimate that there were about 3.4 seroconversion samples from among the 698 191 blood units (that is, $2 / 0.58=3.4$ ). If we assume that each EIA test has a 50\% chance of detecting these low-reactive samples, only 1 more case for every 410700 units of donated blood would be detected by using two different EIA screening tests as compared to using a single EIA screening test (that is, 698 $191 /(3.4 \times 0.5)=410700)$.

To summarize, we have shown that the use of two screening EIAs rather than just one was of virtually no value in our São Paulo blood donor population, and that the use of a second EIA test to detect HIV-positive blood donations does not contribute to blood safety in practical terms. That is because the great majority of HIV-positive donors have already seroconverted and will be detected using only a single EIA screening test. Only persons who are going through the process of seroconversion may be missed by using a single EIA test and detected using two EIAs for screening. For screening out these individuals, other techniques, such as p24 or nucleic acid testing, are known to be more effective than the use of two different, concomitant EIA tests. Furthermore, these other tests also detect HIV-antibody-negative cases that would still be missed even when performing two different, concomitant EIA screening tests.

Acknowledgments. The authors thank Dr. Allen Mayer for critical discussion and suggestions. 


\section{REFERENCES}

1. Weber B, Moshtaghi-Boronjeni M, Brunner M, Preiser W, Breiner M, Doerr HW. Evaluation of the reliability of 6 current anti-HIV-1/HIV-2 enzyme immunoassays. J Virol Methods 1995; 55(1):97-104.

2. Koch WH, Sullivan PS, Roberts C, Francis K, Downing R, Mastro TD, et al. Evaluation of United States-licensed human immunodeficiency virus immunoassays for detection of group M viral variants. J Clin Microbiol 2001; 39(3):1017-1020.

3. George JR, Schochetman G. Detection of HIV infection using serological techniques. In: Schochetman G, George JR, eds. AIDS testing: a comprehensive guide to technical, medical, social, legal and management issues. New York: Springer Verlag; 1994. Pp. 62-102.

4. United States of America, Centers for Disease Control and Prevention. Current trends up- date: serologic testing for antibody to human immunodeficiency virus. MMWR 1988;36(52): 833-840.

5. Proffitt MR, Yen-Lieberman B. Laboratory diagnosis of human immunodeficiency virus infection. Infect Dis Clin North Am 1993;7(2): 203-219.

6. Apetrei C, Loussert-Ajaka I, Descamps D, Damond F, Saragosti S, Brun-Vezinet F, et al. Lack of screening test sensitivity during HIV-1 non-subtype B seroconversions. AIDS 1996; 10(14):F57-60.

7. Ascher DP, Roberts C. Determination of the etiology of seroreversals in HIV testing by antibody fingerprinting. J Acquir Immune Defic Syndr 1993;6(3):241-244.

8. Sabino EC, Delwart E, Lee TH, Mayer A, Mullins JI, Busch MP. Identification of lowlevel contamination of blood as basis for detec- tion of human immunodeficiency virus (HIV) DNA in anti-HIV-negative specimens. J Acquir Immune Defic Syndr 1994;7(8):853-859.

9. Sayre KR, Dodd RY, Tegtmeier G, Layug L, Alexander SS, Busch MP. False-positive human immunodeficiency virus type 1 western blot tests in noninfected blood donors. Transfusion 1996;36(1):45-52.

Manuscript received 11 February 2002. Revised version accepted for publication on 5 August 2002
RESUMEN

Evaluación del uso concomitante de dos inmunoensayos enzimáticos distintos para el tamizaje del $\mathrm{VIH}$ en bancos de sangre
Objetivo. En 1998, el Ministerio de Salud de Brasil decretó que todos los bancos de sangre en el país debían someter toda la sangre donada a un tamizaje para la detección del virus de la inmunodeficiencia humana (VIH) usando concomitantemente dos inmunoensayos enzimáticos (IEE) diferentes. Nuestro objetivo al realizar el presente estudio, resultado de un afán por sacar el máximo provecho a los recursos disponibles, ha sido evaluar la utilidad de hacer un tamizaje con dos IEE en lugar de uno solo.

Métodos. Analizamos datos de 1999-2001 obtenidos como resultado del tamizaje de 698191 unidades de sangre donada mediante dos IEE aplicados concomitantemente en la Fundación Pro-Sangre del Centro de Sangre de São Paulo (Fundação PróSangue/Hemocentro de São Paulo), que es un centro hematológico importante en la ciudad de São Paulo, Brasil. Toda muestra que fue reactiva en por lo menos uno de los dos IEE fue sometida a un inmunoblot de Western (WB) a manera de confirmación, y a las personas que habían donado la sangre positiva también se les pidió que regresaran para proporcionar una muestra de seguimiento.

Resultados. De las 698191 unidades de sangre que fueron donadas, hubo que descartar $2718(0,4 \%)$ porque mostraron reactividad a uno de los IEE o ambos. Dos de las muestras donadas que mostraron positividad en el WB fueron reactivas en solamente uno de los IEE de tamizaje. En lo que respecta a las muestras de seguimiento, ambos donantes tuvieron resultados negativos en el WB. Estos resultados se consideraron positivos falsos para fines del tamizaje. De los 2718 donantes a quienes se les pidió que regresaran para proporcionar una muestra de seguimiento, 1576 (58\%) cumplieron. De estas 1576 personas, dos habían mostrado reactividad a solamente uno de los IEE de tamizaje, con resultados negativos en el WB, pero habían mostrado una seroconversión completa en la muestra de seguimiento. Por consiguiente, nuestra conclusión es que el tamizaje con dos IEE, en comparación con uno solo, permitiría detectar solamente una muestra adicional de un total de 410700 unidades de sangre.

Conclusiones. Nuestros datos no respaldan la conveniencia de usar concomitantemente dos IEE diferentes para el tamizaje del VIH. La gran mayoría de los donantes con positividad a VIH ya habrán tenido una seroconversión y se pueden detectar con un solo IEE. Solamente aquellas personas que están aún en proceso de seroconversión podrían no ser detectadas mediante un solo IEE, pero sí con dos. Para identificar a estas personas y reducir cualquier riesgo residual de transmitir el VIH por medio de la sangre donada en nuestro centro, sería más eficaz el uso de otras técnicas, tales como las pruebas a base de ácidos nucleicos o un ensayo a base de Agp24. 